\title{
Long-term reduced spawning in Orbicella coral species due to temperature stress
}

\author{
Don R. Levitan ${ }^{1, *}$, William Boudreau ${ }^{1}$, Javier Jara ${ }^{2}$, Nancy Knowlton ${ }^{3}$ \\ ${ }^{1}$ Department of Biological Science, Florida State University, Tallahassee, Florida 32306-4295, USA \\ ${ }^{2}$ Smithsonian Tropical Research Institute, Apartado 2072, Balboa, Republic of Panama \\ ${ }^{3}$ Department of Invertebrate Zoology, National Museum of Natural History, Smithsonian Institution, Washington, \\ DC 20013-7012, USA
}

\begin{abstract}
We examined the long-term reproductive consequence of bleaching stress on Caribbean corals in the Orbicella (formerly Montastraea) species complex $(O$. annularis, $O$. faveolata, and $O$. franksi). Over 2000 observations of spawning in 526 tagged corals in Panama were made from 2002 through 2013. Bleaching events were noted in 2005 and 2010. At the population level, a reduction in spawning persisted for several years following each bleaching event. In 2010, (1) the bleaching event did not alter the timing of spawning, nor coral survivorship or tissue loss; (2) both bleached and unbleached corals had a reduced probability of spawning for several years following the bleaching event, and corals that visibly bleached were less likely to spawn than corals that did not visibly bleach; (3) the species that was affected most by the bleaching event $(O$. annularis) recovered the ability to spawn in fewer years compared to the species least affected by the bleaching event (O. franksi); and (4) in O. franksi, the species with the widest depth distribution, recovery in the likelihood to spawn was not depth related, although individuals at greater depths were less likely to bleach. In sum, corals that recover from bleaching events can experience long-term reduction in reproduction, over time scales that can bridge the interval between subsequent bleaching events. This may be catastrophic for the long-term maintenance of the population.
\end{abstract}

KEY WORDS: Allee effects - Coral bleaching • Fertilization $\cdot$ Spawning $\cdot$ Synchrony

Resale or republication not permitted without written consent of the publisher

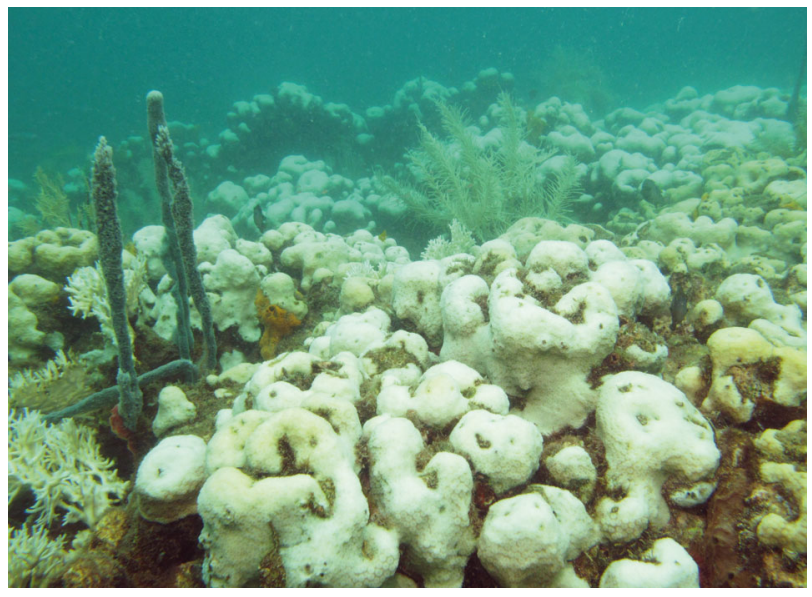

A severe coral bleaching event reduced the likelihood of spawning in both visibly bleached and unbleached corals for 4 years.

Photo: Raphael Ritson-Williams

\section{INTRODUCTION}

Corals that are stressed can experience a breakdown of the symbiosis with their photosynthetic partners, resulting in a bleached appearance. This bleaching stress is often induced by high temperatures and solar irradiance (Coles \& Jokiel 1978, Fitt \& Warner 1995, Brown 1997, Hoegh-Guldberg 1999, Eakin et al. 2010, Downs et al. 2013); it can also be caused by low pH (Kaniewska et al. 2012) and other stressors such as reduced salinity, pathogen infection, and cold stress (reviewed in Brown 1997). Depending 
on the severity of the bleaching event, corals might die or recover, with the algal symbionts recolonizing the coral hosts after the stress is reduced (Eakin et al. 2010). More severe events typically lead to lengthier recovery times for affected colonies, increasing the mortality by delaying symbiont recolonization. Corals that do survive bleaching events have diminished growth (Suzuki et al. 2003), lower resistance to disease (Harvell et al. 1999), and reduced reproductive output (Szmant \& Gassmann 1990, Coles \& Brown 2003).

The reproductive consequences of bleaching stress include decrease in gametogenesis, egg size, fecundity, and spawning (Szmant \& Gassmann 1990, Mendes \& Woodley 2002, Cox 2007). The reproductive costs of bleaching stress relate to the severity of the bleaching event. Corals that appeared to recover after 3 to 6 mo often did not show reproductive consequences (Szmant \& Gassmann 1990, Cox 2007), while corals that took $\geq 8$ mo to recover had diminished gametogenesis in the months leading up to the next spawning event (Szmant \& Gassmann 1990). Mendes \& Woodley (2002) documented a 2 yr reduction in gonad development for mildly affected (bleached for $2 \mathrm{mo}$, pale for $5 \mathrm{mo}$ ) and more severely affected (bleached for $4 \mathrm{mo}$, pale for $7 \mathrm{mos}$ ) corals. Corals on reefs exposed to frequent bleaching events appear to partially acclimate to the stress and reproduce at a greater rate compared to corals on reefs bleaching less frequently (Armoza-Zvuloni et al. 2011).

Members of the Orbicella (formerly Montastraea) annularis species complex are dominant reef builders of the Caribbean (Goreau 1959) and consist of 3 taxa: O. annularis sensu stricto, O. faveolata, and O. franksi (Knowlton et al. 1992, Weil \& Knowlton 1994). O. faveolata separated from the other 2 taxa 3 to 5.5 million years ago (mya), whereas O. franksi and $O$. annularis diverged 0.5 to 2 mya (Fukami et al. 2004). The 3 species are distinguished by slight differences in morphology, ecology, aggressive behavior, and genetics (Lopez et al. 1999, Fukami et al. 2004, Fukami \& Knowlton 2005, Pandolfi \& Budd 2008). Corals in this species complex are hermaphroditic external fertilizers that undergo annual mass spawning (Szmant 1991, Van Veghel 1994, Van Veghel \& Bak 1994, Van Veghel \& Kahmann 1994, Knowlton et al. 1997, Szmant et al. 1997, Hagman et al. 1998, Levitan et al. 2004). Individual polyps of corals annually produce a single gamete bundle containing sperm and eggs. These bundles become visible on the surface of the corals about 30 min prior to spawning (termed 'setting'). Once released, these bundles rise to the surface and break apart where they can be fertilized by non-self gametes.

All 3 taxa spawn 4 to $8 \mathrm{~d}$ after the full moon in late summer or early fall, depending on the calendar date of the lunar period and on latitude (Gittings et al. 1992, Knowlton et al. 1997, Szmant et al. 1997, Levitan et al. 2004). In Panama, the peak is in September (Levitan et al. 2011). On the evenings of spawning, synchrony is tight; most individuals within a species spawn within around $20 \mathrm{~min}$, and the range is approximately $1 \mathrm{~h}$ (Levitan et al. 2004, 2011). The timing of these events is also highly predictable; at our study site in Panama, O. franksi spawns approximately 115 min after sunset, while $O$. annularis and O. faveolata spawn 225 and 235 min after sunset, respectively, consistent with other locations in the Caribbean (reviewed in Levitan et al. 2004). The cue for spawning time appears to be sunset; regional differences in spawning times can be explained by adjusting for local sunset time, and corals can be induced experimentally to spawn early by placing them in darkness prior to sunset (Knowlton et al. 1997, Levitan et al. 2004, Brady et al. 2009). For an individual coral colony, the standard deviation in the timing of spawning across years is 7, 10, and $14 \mathrm{~min}$ for $O$. franksi, $O$. annularis, and $O$. faveolata, respectively (Levitan et al. 2011). The variation among corals within a species in spawning time has genetic, environmental, and timing components; clone mates spawn more synchronously than non-clone mates, neighbors spawn more synchronously than more distantly located individuals regardless of relatedness, and individuals with a mean spawn time closer to sunset have lower yearly variation in spawn time (Levitan et al. 2011).

Interspecific gametic compatibility varies across these species. The 2 species with overlapping spawning times, O. faveolata and $O$. annularis, produce gametes that are largely incompatible with each other; the exceptions are as infrequent as self-crosses and not statistically different from $0 \%$ fertilization (Levitan et al. 2004). Two species with non-overlapping spawning times, the early-spawning O. franksi and the later-spawning $O$. annularis, have compatible gametes (Levitan et al. 2004); however, they show conspecific sperm precedence (Fogarty et al. 2012a).

Previous studies focused on detailed investigations of aspects of gametogenesis and gonad development in a small number of samples $(\sim 10$ per treatment group), over several months to 2 yr. Here we examine spawning observations from a larger population of tagged individuals across 3 congeneric species over a 12 yr period covering 2 bleaching events, as well as 
changes in percent live tissue cover as a function of bleaching.

\section{MATERIALS AND METHODS}

Observations of coral spawning were conducted at a permanent transect $(100 \mathrm{~m}$ along the $4 \mathrm{~m}$ depth contour $\times 30 \mathrm{~m}$ perpendicular to this contour) on a reef at Bocas del Toro, Panama $\left(9^{\circ} 19^{\prime} 38^{\prime \prime} \mathrm{N}\right.$, $82^{\circ} 12^{\prime} 14^{\prime \prime} \mathrm{W}$ ). The site varies from 3 to $8 \mathrm{~m}$ in depth, with Orbicella franksi in the deeper and $O$. annularis in the shallower locations, but these species overlap in depth and can grow into contact with each other (Levitan et al. 2011). We observed, tagged, and genotyped 526 spawning corals for a total of 2340 observations of setting or spawning from 2002 through 2013. Of these colonies, based on morphological and genetic data, 397 are $O$. franksi colonies ( 375 unique genets), 119 are $O$. annularis (21 unique genets), and 10 are $O$. faveolata (3 unique genets). Coral ramets within a genet tended to be spatial neighbors, but some spatial mixing was noted among genets (Levitan et al. 2011).

Observations of spawning at this site began in 2000 (Levitan et al. 2004). The mapping, tagging, and genotyping of individual corals observed to spawn were initiated in 2002 and continued each year through 2013. On each evening of observation, 6 to 12 divers surveyed the site from 19:45 $\mathrm{h}$ (approximately 15 min prior to the first observation of 'setting') to $22: 30 \mathrm{~h}$ (approximately $30 \mathrm{~min}$ after the last observation of spawning) from Day 4 through Day 7 following the full moon in September (Day $0=$ day of full moon). From 2002 until 2011, divers recorded the setting and spawning times of any corals within the transect observed to spawn, and colonies seen to spawn for the first time were identified with a weighted and numbered chemical light. These new corals were then marked with a numbered aluminum tag, depth noted, spatial position mapped, and a tissue sample taken for genetic analysis. Colony size (longest diameter, perpendicular diameter, and height) was also recorded for each tagged coral. For spawning corals tagged during previous seasons, the tag number was recorded with the spawning observation. After 2011, because of the burgeoning number of tagged colonies and time constraints, only previously tagged corals were monitored. The percent cover of live tissue for each tagged coral was recorded in September 2009, March 2011, September 2012, and September 2013 for O. franksi coral colonies. This was not done for $O$. annularis, because the spatial dimensions of this often fragmenting species would be somewhat arbitrary without a complete genetic analysis of all fragments.

HOBO data loggers were placed on the reef to record water temperature and light intensity (luminosity per $0.093 \mathrm{~m}^{2}\left[=1 \mathrm{ft}^{2}\right]$ ), every $30 \mathrm{~s}$, for the week (Day 2 to Day 9 following full moon) of the coral spawn in years 2007 through 2013. One HOBO was placed at each meter of depth from 1 to $8 \mathrm{~m}$. A series of 9 additional HOBOs, spaced at approximately $8 \mathrm{~m}$ intervals, were placed along the $4 \mathrm{~m}$ depth contour along the coral transect. Records of sea surface temperature (SST) and degree heating weeks (DHW) for the Bocas Del Toro region from 2002 to 2013 were obtained from a twice-weekly $0.5^{\circ}$ resolution composite satellite radiometer dataset provided by the NOAA Coral Reef Watch (http://coralreefwatch. noaa.gov/satellite/vs/index.php) monitoring program. DHW is an index of accumulated thermal bleaching stress based on SST values from the previous $12 \mathrm{wk}$ and represents the cumulative degrees of positive temperature anomalies from the highest mean monthly SST values previously recorded at the location. Scores exceeding a threshold value of 4 indicate stress levels likely to result in coral bleaching, while scores $>8$ are associated with widespread bleaching events (Liu et al. 2003).

We noted 2 bleaching events. The first was in September 2005, which coincided with Caribbean-wide observations of high SST and coral bleaching (Eakin et al. 2010). We observed partial bleaching, particularly in $O$. annularis, but at the time did not record which of our tagged colonies did or did not bleach. In the summer of 2010, the bleaching was much more severe, and included many cnidarian species including other corals, hydrozoans, gorgonians, corallimorpharians, and anemones (Fig. 1). This event was ongoing during the September 2010 spawning event, and for each tagged coral colony, the bleaching state was recorded (normal, pale blotches, pale, white). Because of the severity of the event, we returned to the site during 10 to 13 March 2011 to record the bleaching status and percent live tissue cover following this event.

\section{RESULTS}

Monitoring of spawning in our tagged colonies indicated that the number of spawning corals increased each year until a bleaching event (2005 and 2010), during and after which rates of spawning across the reef were reduced (Fig. 2). In the years prior to the 

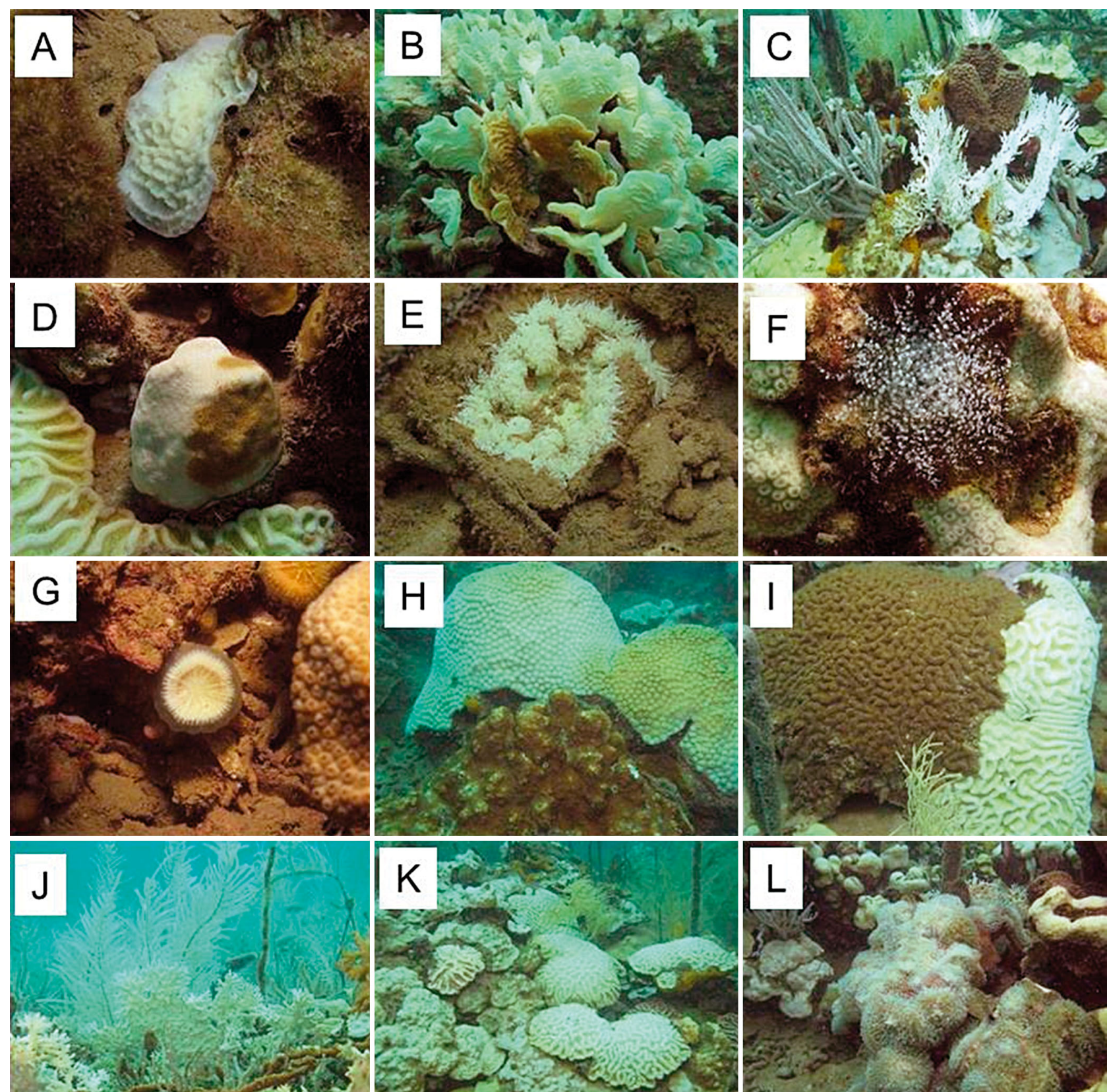

Fig. 1. Bleaching event at the transect. (A) Leptoseris cucullata; (B) Agaricia tenuifolia; (C) hydrozoan Millepora alcicornis; (D) partially bleached Stephanocoenia intersepta and Colpophylia natans; (E) anemone Epicystis crucifer; (F) anemone Ragactis lucida; (G) Scolymia cubensis; (H) Montastraea cavernosa; (I) Colpophylia natans, unbleached half is overgrown by the sponge Chondrilla nucula; (J) octocoral Pseudopterogorgia spp. and hydrozoan Millepora alcicornis; (K) bleached transect site; (L) corallimorpharian Rhodactis osculifera. Photos: Raphael Ritson-Williams

bleaching events $(2004,2009)$ we observed 129 and 347 of our tagged coral colonies spawning. During the years of bleaching, there was a reduction of $38 \%$ and $79 \%$ (2005) and $53 \%$ and $95 \%$ (2010) for Orbicella franksi and $O$. annularis, respectively. The overall increasing number of spawning $O$. franksi from the first few years (2002-2007) to more recent years
(2008-2013) might be partially caused by divers collecting additional data on fertilization rates as well as set and spawn time in those earlier years (see Levitan et al. 2004). By 2008, all divers were focused on collecting set and spawn times. In any case, the increased attention to set and spawn times between 2007 and 2008 does not explain the declines in the 


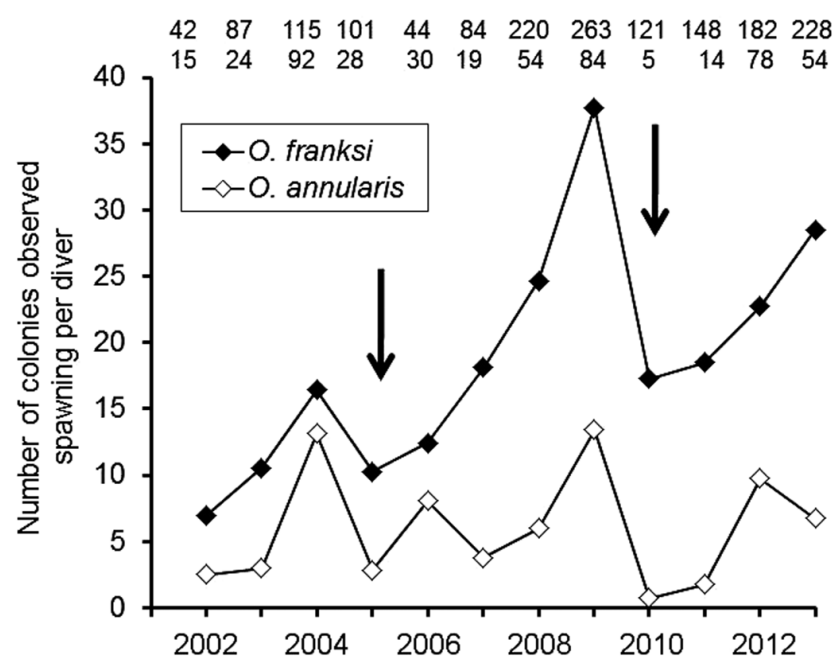

Fig. 2. Mean number of coral colonies observed to spawn per diver within the transect for Orbicella franksi and $O$. annularis. Arrows indicate bleaching events in 2005 and 2010, numbers are total observed tagged corals spawning (O. franksi above, O. annularis below) number of observed corals spawning during and following bleaching events. Although we did not collect quantitative data on the fraction of coral polyps that release gamete bundles during a spawn, we did note qualitatively that during the years of bleaching, partially spawning colonies or colonies releasing only a few gamete bundles were often observed.

Data on sea temperatures collected at our site since 2007 indicate that although peak and overall average water temperatures in 2010 were not abnormally high during the week of spawning, there was a notable absence of a thermocline that year, with negligible changes in water temperature across depth, and warmer average temperatures at depths of 5 to $8 \mathrm{~m}$ than during any other monitored year (Fig. 3a). In all other years in which we collected temperature data, we observed a clear pattern of decreasing temperature with depth. Data collected from the CRW virtual station for Bocas del Toro revealed high levels of thermal stress during the late summer and fall months of
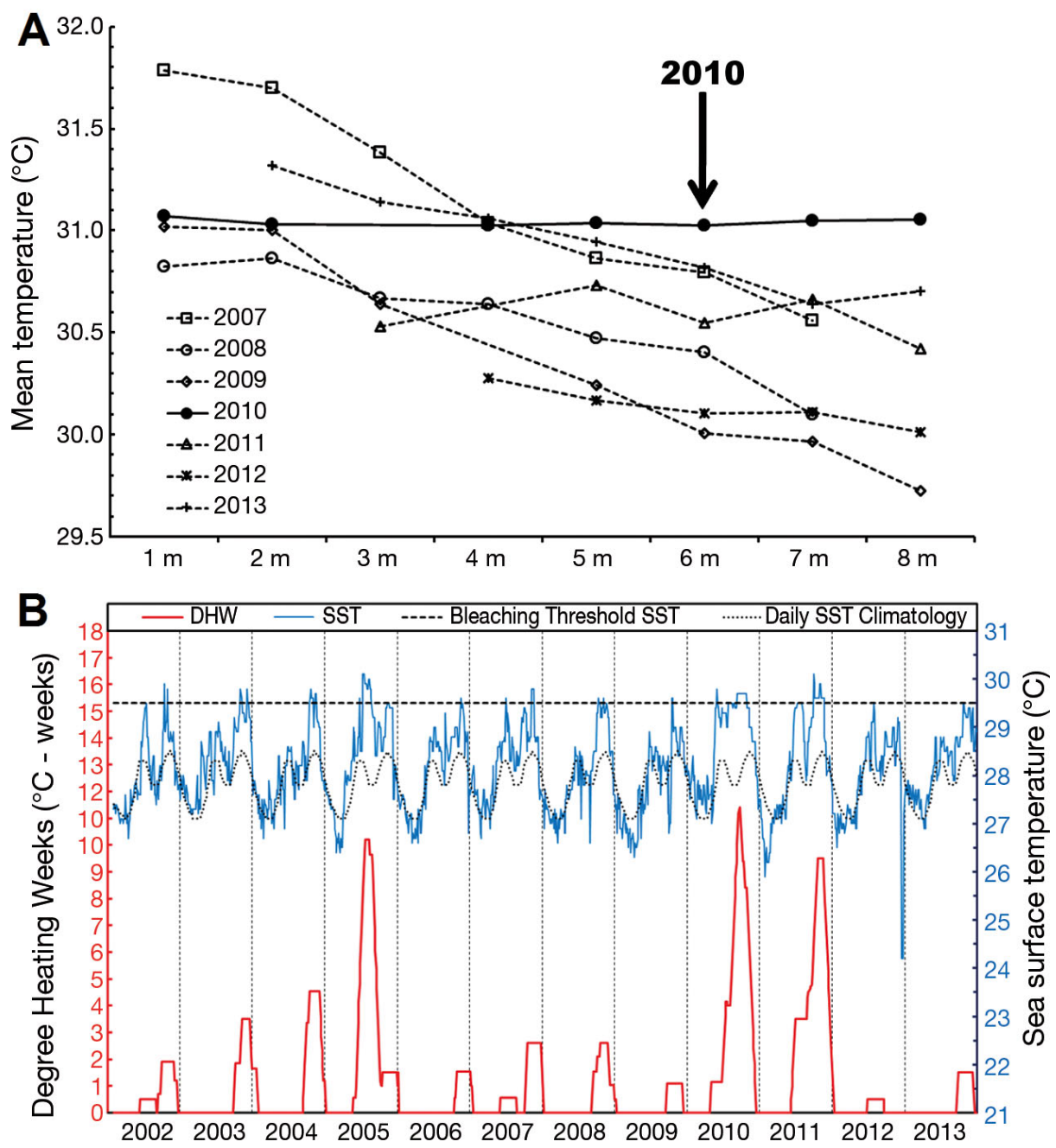

Fig. 3. (A) Mean temperatures at the transect site from 1 to $8 \mathrm{~m}$ depth during coral spawning weeks (6 to $7 \mathrm{~d}$ continuous data collection $\left.\mathrm{yr}^{-1}\right), 2007$ to 2013, recorded by HOBO data loggers. Data for 2010 are indicated with filled circles and highlighted with an arrow. Error bars are too small to display. (B) NOAA Coral Reef Watch (CRW) bi-weekly $50 \mathrm{~km}$ resolution satellite estimates of sea surface temperature (SST) and degree heating weeks (DHW) for Bocas del Toro, Panama $\left(9.5^{\circ} \mathrm{N}\right.$, $\left.81.5^{\circ} \mathrm{W}\right)$. Values for coral bleaching temperature threshold (Bleaching Threshold SST) and daily SST climatologies derived from SST Anomaly and HotSpot data provided by CRW, following methods outlined at http://coralreefwatch. noaa.gov/satellite/methodology/ methodology.php. DHW values $>4$ are correlated with coral bleaching; values $>8$ are considered high risk for widespread bleaching and coral mortality (Liu et al. 2003) 
2005, 2010, and 2011, with DHW index scores for each year exceeding 8 , indicating the presence of thermal stress levels associated with widespread bleaching (Fig. 3b). High thermal stress scores during 2005 were driven by sharp early June increases in SST which persisted through much of July, resulting in a period of high cumulative thermal stress between late July and mid-September. CRW data show that during 2010, when we observed extensive bleaching at the monitoring site, SST increased above the maximum mean expected values in mid-April and remained elevated until mid-October, resulting in the highest DHW index scores recorded in Bocas from 2002 to 2013 (10.5 to 11.4), with cumulative stress levels peaking in September and remaining elevated beyond the high bleaching threshold until the end of October. We did not directly observe additional bleaching at our spawning site during our September monitoring trip in 2011 (or in 2012), but CRW data suggest that another thermal stress event occurred later that year, resulting in DHW scores as high as 9.5 from midOctober through mid-November.

Because the bleaching event was severe in 2010 and because we had noticed a population level effect on spawning rates following the 2005 event, we recorded the bleaching state of all tagged corals during the spawning event of 2010. Almost all tagged $O$. annularis colonies bleached, most of the $O$. faveolata bleached, and half of the O. franksi colonies bleached in 2010 (Table 1). Although these species have overlapping depth distributions at this site, the differences in the proportion of bleached colonies, among species, is correlated with depth distribution, with $O$. annularis and $O$. franksi having the shallowest and deepest distribution, respectively. Within species, colonies that did not show signs of bleaching, or showed a pale rather than bone white appearance, had a deeper depth distribution (Table 1). In our survey on 10 to 13 March 2011 (5.5 mo after the September 2010 spawning/bleaching event), we detected no signs of bleaching in any corals or mortality in any tagged colonies.

Table 1. Proportion of Orbicella coral colonies that appeared normal color, pale (or pale blotches) and totally bleached (white) in September 2010. The mean (standard error) depth $(\mathrm{m})$ of corals with different bleaching state is reported

\begin{tabular}{|lcccccc|}
\hline State & \multicolumn{2}{c}{ O. annularis } & \multicolumn{2}{c|}{ O. faveolata } & \multicolumn{2}{c|}{ O. franksi } \\
& Prop. & Depth (SE) & Prop. & Depth (SE) & Prop. & Depth (SE) \\
\hline Normal & 0.01 & $4.0(-)$ & 0.20 & $5.20(0.30)$ & 0.49 & $5.61(0.08)$ \\
Pale & 0.81 & $3.18(0.10)$ & 0.80 & $3.90(0.28)$ & 0.50 & $4.34(0.07)$ \\
White & 0.99 & $2.49(0.07)$ & 0.00 & - & 0.01 & $4.67(0.53)$ \\
\hline
\end{tabular}

We did not detect any effect of the 2010 bleaching event on the timing of spawning for O. franksi. Bleached (1 h $48 \mathrm{~min} \pm 12 \mathrm{~min}$ SD past sunset) and unbleached corals ( $1 \mathrm{~h} 45 \mathrm{~min} \pm 12 \mathrm{~min}$ ) did not differ in their time of spawning in 2010 (Student's $t=0.60$, nonsignificant, NS) and on average, individual colonies, regardless of bleaching status, spawned within $10 \mathrm{~min}$ (mean $10 \mathrm{~min}$ for both states, \pm 18 and $\pm 7 \mathrm{~min}$ for bleached and normal corals, respectively) of their individual mean spawn time across non-bleaching event years (Student's $t=0.03, \mathrm{NS}$ ); the standard deviation for individual colony spawn time, across years, for this site and species is $7 \mathrm{~min}$ (Levitan et al. 2011).

We did detect differences in the likelihood of spawning associated with bleaching, not only during the bleaching event, but for several years following the bleaching event (Fig. 4). For O. franksi in the year prior to the 2010 bleaching event, there was no difference in the percentage of colonies spawning between corals that were going to bleach in 2010 and those that did not bleach in 2010 (Fisher's exact test, NS). Therefore, prior to the bleaching event, corals that did bleach were no less reproductively active compared to those that did not bleach. In 2010, during the bleaching event, corals that were bleached were half as likely to spawn as unbleached colonies (Fisher's exact test, p $<0.0001$ ), and overall, both bleached and unbleached corals were half as likely to spawn compared to 2009 (Fisher's exact test, p < 0.0001). In 2011 and 2012, the differences in the likelihood of spawning between corals that did or did not bleach diminished but was still significantly different, as was the overall likelihood to spawn compared to 2009 (Fig. 6). By 2013, these differences were no longer significant, but the overall percentage of tagged corals observed to spawn was still slightly and significantly reduced compared to 2009 (50\% vs. $58 \%$, Fisher's exact test, $\mathrm{p}=0.0326)$. For $O$. annularis, the patterns were originally more striking, but the recovery appeared to be more rapid. Only $4 \%$ of pale colonies and $10 \%$ of bone-white colonies were observed to spawn in 2010, and all of these observations were of partially spawning colonies in which only a small percentage of polyps released gamete bundles. The following year was also a poor year for $O$. annularis $(15 \%$ of pale and $0 \%$ of white colonies observed to spawn), but by 2012 , these proportions (59\% for pale and $58 \%$ for white) were similar to 2009 $(59 \%, 52 \%)$, the year prior to the bleaching event (Fisher's exact test, NS for 2012 and 2013). 

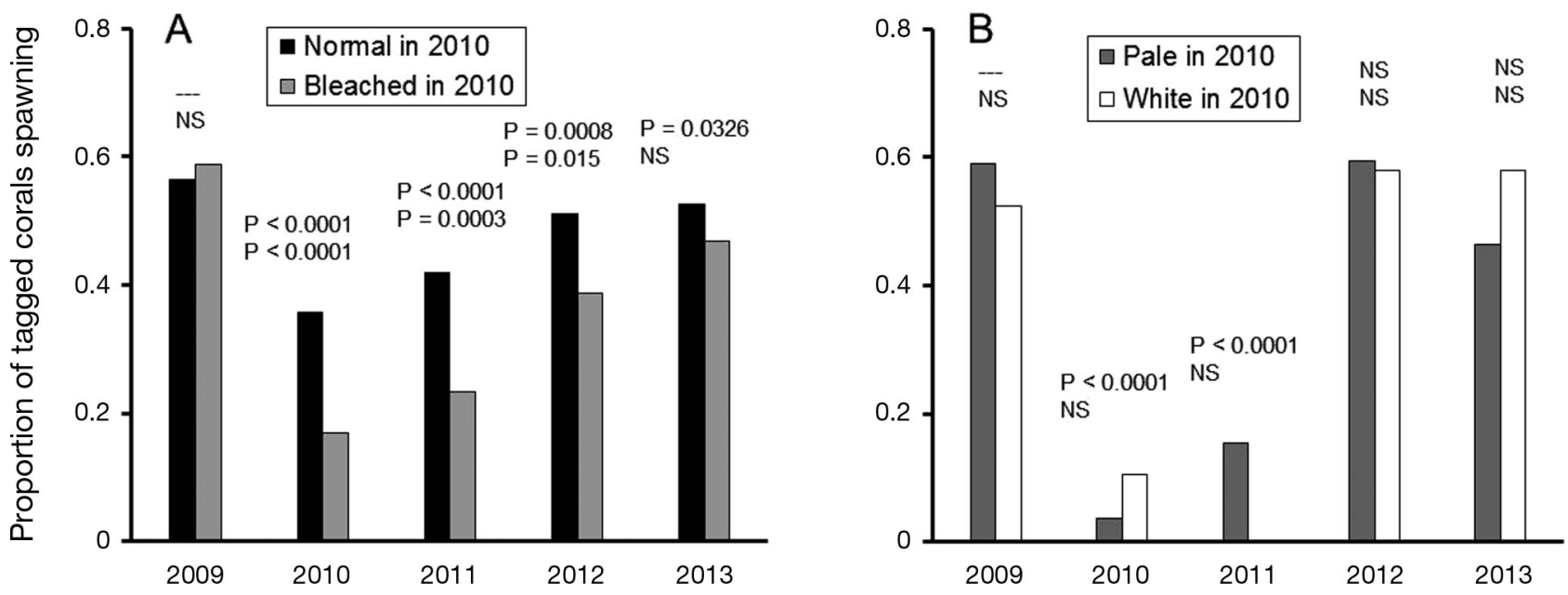

Fig. 4. Proportion of colonies that spawned through time as a function of bleaching status in 2010: (A) bleached (any amount of bleaching) versus normal in Orbicella franksi, (B) pale versus white in $O$. annularis (there were no normal colored $O$. annularis in 2010). Top and bottom significance levels refer to Fisher's exact tests examining the likelihood of all corals spawning in one year compared to 2009 (top) and the difference in the likelihood to spawn in that year between corals that bleached or did not bleach in 2010 (bottom; NS: non-significant)

For $O$. franksi, we used a repeated measure, categorical analysis (CATMOD; SAS) to examine the proportion of individuals spawning as a function of 3 depth categories $(<4,4-6,>6 \mathrm{~m}), 2$ states (bleached or unbleached in 2010), and the repeated measure of time (2010 to 2013, Fig. 5). We noted a significant effect of bleaching state $(p<0.0001)$ and year $(p<$ $0.0001)$, but not depth category ( $\mathrm{p}=0.17$ ) or any 2 - or 3 -way interaction (Table 2). Thus, in this species and after accounting for bleaching status, we could not

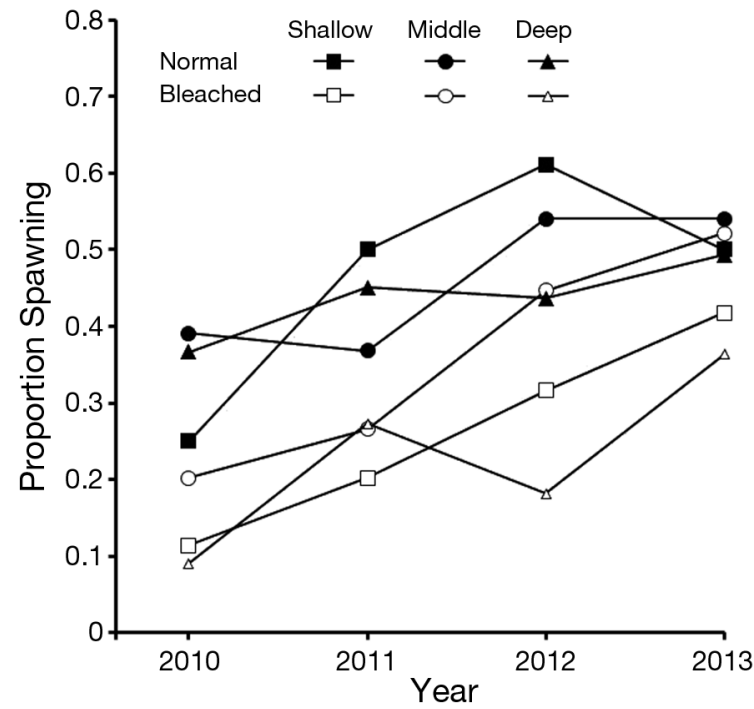

Fig. 5. Proportion of Orbicella franksi spawning as a function of bleaching status in 2010 (normal or bleached), depth of colony (shallow $<4 \mathrm{~m}_{\text {; }}$ middle 4-6 $\mathrm{m}$; deep $>6 \mathrm{~m}$ ) and year. Bleaching state and year significantly influenced spawning, but not depth or any interaction (see Table 2) detect an effect of depth on the probability to spawn during the bleaching event or in subsequent years, nor any indication that corals recovered their likelihood to spawn as a function of depth.

We did not detect mortality in any tagged corals from prior to the event in 2009 through the 2013 census. Overall, over this decadal monitoring period, only 1 small $O$. franksi colony perished. Comparing patterns of live tissue gain and loss from prior to the bleaching event in 2009 to 2013, on average there has been a $6 \%$ loss of tissue $( \pm 1 \% \mathrm{SE})$, but no significant difference in the degree of tissue loss or gain as a function of whether the corals appeared bleached during the 2010 event $\left(F_{319,1}=0.61, p=0.61\right)$. Overall, the largest shift in percent live tissue cover was

Table 2. Categorical analysis (CATMOD, SAS) of the observation of an Orbicella franksi coral colony spawning as a function of State (bleached or unbleached in 2010) and Depth category $(<4,4-6,>6 \mathrm{~m})$ as main effects, and the repeated measure of year $(2010,2011,2012,2013)$

\begin{tabular}{|c|c|c|c|}
\hline $\begin{array}{l}\text { ANOVA } \\
\text { Source }\end{array}$ & df & $\chi^{2}$ & $\mathrm{p}$ \\
\hline Intercept & 1 & 956.09 & $<0.0001$ \\
\hline Bleaching state & 1 & 18.05 & $<0.0001$ \\
\hline Depth & 2 & 3.55 & 0.1696 \\
\hline Year & 3 & 39.47 & $<0.0001$ \\
\hline State $\times$ Depth & 2 & 2.33 & 0.3116 \\
\hline Depth $\times$ Year & 6 & 9.19 & 0.1633 \\
\hline State $\times$ Year & 3 & 3.77 & 0.2876 \\
\hline State $\times$ Depth $\times$ Year & 6 & 3.35 & 0.7636 \\
\hline
\end{tabular}


noted between 2012 and 2013 (5\% loss). Although our annual visits to this site cannot capture all of the relevant factors that might influence tissue growth and loss, we did note a high degree of sedimentation in September 2013, which might have contributed to tissue loss.

\section{DISCUSSION}

The most striking result from these observations is that conditions that resulted in bleaching events influenced the probability of coral spawning for several years, even in corals that did not bleach, but more so in corals that did bleach. The $4-5 \mathrm{yr}$ recovery time of spawning at the population level noted following the 2005 bleaching event mirrored the more detailed response noted during the 2010 bleaching event. In Bocas del Toro, the 2010 event appeared to be much more severe in Orbicella and widespread across many taxa, compared to 2005, when bleaching was serious and widespread across the Caribbean (Eakin et al. 2010). O. annularis, which inhabits generally shallower water, was nearly completely bleached (99\%) during the 2010 event and experienced near complete reproductive failure, while $O$. franksi, with an overlapping but slightly deeper distribution, experienced less intense bleaching of individuals, a lower frequency of bleached individuals, and a higher probability of spawning. In $O$. franksi, bleached corals were $50 \%$ less likely to spawn than unbleached conspecifics, but both bleached and unbleached individuals were less likely to spawn compared to years prior and following the bleaching event. Although O. annularis appeared to be more stressed and was less likely to spawn during the 2010 event, this shallower species, which also showed signs of bleaching in 2005, exhibited a more rapid recovery over the subsequent $3 \mathrm{yr}$ interval. Reefs with a history of frequent bleaching events are more resilient to these events (Armoza-Zvuloni et al. 2011). The pattern noted among these Orbicella species indicates that this is also true within a reef among species. In O. franksi, although there was a depth gradient in the severity of the bleaching event, there was no evidence that depth influenced the likelihood to spawn or the rate of recovery of the likelihood to spawn over time; corals that bleached, regardless of depth, had mostly, but not entirely, recovered the ability to spawn over a $3 \mathrm{yr}$ interval.

The 2010 bleaching events did not significantly influence the timing of spawning or the degree of synchrony. It did affect the likelihood to spawn, and qualitatively it was noted that during the 2010 event many corals that did spawn, did so partially. This set of results suggests that the reproductive consequence of bleaching in Orbicella is in energy lost or diverted from reproduction to other functions. We found no evidence that disrupting the coral association with its photosynthetic partner influences how sunlight (Knowlton et al. 1997, Levitan et al. 2004, Brady et al. 2009) or moonlight (Levy et al. 2007, Sweeney et al. 2011) cue the timing of spawning.

We also did not detect any influence of the bleaching events on survivorship. In spite of reef-wide bleaching among diverse taxa, Orbicella colonies at our site were able to quickly recover their symbionts and eventually recovered the ability to reproduce. Other species did not fare as well, and although we do not have quantitative data, most colonies of Colpophylia natans (Fig. 1I) at our transect site perished from the 2010 event.

Monitoring of temperature data indicate that 2005 and 2010 were on the order of $0.5^{\circ} \mathrm{C}$ warmer in September/October during the spawning season for Orbicella. Detailed temperature profiles during the week of spawning indicate that for 2010 (no data for 2005), the most striking feature was the absence of a thermocline on this reef, resulting in water temperatures 0.5 to $1.2^{\circ} \mathrm{C}$ warmer than usual at the deeper sections of this reef $(4-8 \mathrm{~m})$, exposing these corals to unusually high temperatures in excess of $31^{\circ} \mathrm{C}$. Persistent temperature increases on the scale of $1^{\circ} \mathrm{C}$ have previously been associated with mass bleaching events (Baker et al. 2008).

The likelihood of fertilization is a function of the intensity of the spawning event for Orbicella on this reef and other reefs in the Caribbean (Levitan et al. 2004), and in other soft (Lasker et al. 1996) and hard coral species (Oliver \& Babcock 1992). Corals that spawn on off-peak nights when a smaller fraction of corals release gametes appear to have near complete reproductive failure (Levitan et al. 2004). Even corals that spawn during peak nights, but at the tails of the distribution of spawn time, have lower fertilization success than corals that spawn in tight synchrony with neighbors (Levitan et al. 2004). Although we did not detect any evidence that these bleaching events disrupted the timing of spawning, it did severely reduce the population density of spawning individuals and qualitatively reduced the reproductive output of those corals that did spawn. These factors would substantially reduce the likelihood of sperm-egg encounters and fertilization success. Reduced reproductive success may persist over several years as these corals slowly recover their repro- 
ductive potential. If bleaching events occur at a frequency of 2 to 3 events per decade, our data suggest that at least these coral species would constantly be in a condition of reproductive recovery and diminished reproductive output and success. In addition to bleaching stress, the presence of macroalgae on reefs can interact with Orbicella and reduce both egg size and number (Foster et al. 2008). Thus both the increased thermal stress, and reduced herbivory, are likely to reduce the reproductive potential of these corals.

A secondary consequence of reduced spawning density is the potential loss of conspecific sperm precedence as a mechanism of reproductive isolation (Fogarty et al. 2012a). Sperm precedence can only discriminate among sperm types when they arrive at an egg simultaneously, an event that is more likely when corals spawn at high densities. Thus reduced spawning intensity could facilitate hybridization and reticulate evolution, as has been suggested for Caribbean Acropora corals (Fogarty et al. 2012b).

Historically, massive slow-growing and long-lived corals like Orbicella could likely persist through good and poor reproductive years. However, with the current decadal-scale reduction in coral cover of Orbicella and other massive broadcast spawning species (Edmunds \& Elahi 2007, Carpenter et al. 2008), periodic bleaching events that cause persistent reductions in reproductive output and success might lead to Allee effects (Levitan \& McGovern 2005) and prove catastrophic for population recovery over the long term.

Acknowledgements. We thank M. Adreani, D. Baker, B. Biggs, A. Feuerstein, N. Fogarty, M. Leray, K. Lotterhos, K. Pawlik, L. Plaisance, A. Strimatis, C. terHorst, and other researchers at the Boca del Toro field station for assistance with field work. The government of Panama kindly provided permission for field and laboratory work. Research was funded by NSF OCE-9911225 to D.R.L. and N.K., and support from the Smithsonian Institution to N.K.

\section{LITERATURE CITED}

Armoza-Zvuloni R, Segal R, Kramarsky-Winter E, Loya Y (2011) Repeated bleaching events may result in high tolerance and notable gametogenesis in stony corals: Oculina patagonica as a model. Mar Ecol Prog Ser 426: 149-159

Baker AC, Glynn PW, Riegl B (2008) Climate change and coral reef bleaching: an ecological assessment of longterm impacts, recovery trends, and future outlook. Estuar Coast Shelf Sci 80:435-471

Brady AK, Hilton JD, Vize PD (2009) Coral spawn timing is a direct response to solar light cycles and is not an entrained circadian response. Coral Reefs 28:677-680
Brown BE (1997) Coral bleaching: causes and consequences. Coral Reefs 16:S129-S138

Carpenter KE, Abrar M, Aeby G, Aronson RB and others (2008) One-third of reef-building corals face elevated extinction risk from climate change and local impacts. Science 321:560-563

Coles SL, Brown BE (2003) Coral bleaching - capacity for acclimatization and adaptation. Adv Mar Biol 46:183-223

> Coles SL, Jokiel PL (1978) Synergistic effects of temperature, salinity and light on hermatypic coral Montipora verrucosa. Mar Biol 49:187-195

$>$ Cox EF (2007) Continuation of sexual reproduction in Montipora capitata following bleaching. Coral Reefs 26: 721-724

$>$ Downs CA, McDougall KE, Woodley CM, Fauth JE and others (2013) Heat-stress and light-stress induce different cellular pathologies in the symbiotic dinoflagellate during coral bleaching. PLoS ONE 8:e77173

Eakin CM, Morgan JA, Heron SF, Smith TB and others (2010) Caribbean corals in crisis: record thermal stress, bleaching, and mortality in 2005. PLoS ONE 5:e13969 doi:10.1371/journal.pone.0013969

Edmunds PJ, Elahi R (2007) The demographics of a 15-year decline in cover of the Caribbean reef coral Montastraea annularis. Ecol Monogr 77:3-18

Fitt WK, Warner ME (1995) Bleaching patterns of four species of Caribbean reef corals. Biol Bull (Woods Hole) 189:298-307

Fogarty ND, Lowenberg M, Ojima MN, Knowlton N, Levitan DR (2012a) Asymmetric conspecific sperm precedence in relation to spawning times in the Montastraea annularis species complex (Cnidaria: Scleractinia). J Evol Biol 25:2481-2488

Fogarty ND, Vollmer SV, Levitan DR (2012b) Weak prezygotic isolating mechanisms in threatened Caribbean Acropora corals. PLoS ONE 7:e30486

Foster NL, Box SJ, Mumby PJ (2008) Competitive effects of macroalgae on the fecundity of the reef-building coral Montastraea annularis. Mar Ecol Prog Ser 367:143-152

> Fukami H, Knowlton N (2005) Analysis of complete mitochondrial DNA sequences of three members of the Montastraea annularis coral species complex (Cnidaria, Anthozoa, Scleractinia). Coral Reefs 24:410-417

Fukami H, Budd AF, Levitan DR, Jara J, Kersanach R, Knowlton N (2004) Geographical differences in species boundaries among members of the Montastraea annularis complex based on molecular and morphological markers. Evolution 58:324-337

Gittings SR, Boland GS, Deslarzes KJP, Combs CL, Holland BS, Bright TJ (1992) Mass spawning and reproductive viability of reef corals at the East Flower Garden Bank, northwest Gulf of Mexico. Bull Mar Sci 51:420-428

> Goreau TF (1959) The ecology of Jamaican coral reefs. I. Species composition and zonation. Ecology 40:67-90

Hagman DK, Gittings SR, Deslarzes KJP (1998) Timing, species participation, and environmental factors influencing annual mass spawning at the Flower Garden Banks (Northwest Gulf of Mexico). Gulf Mex Sci 16:170-179

Harvell CD, Kim K, Burkholder JM, Colwell RR and others (1999) Emerging marine diseases - climate links and anthropogenic factors. Science 285:1505-1510

> Hoegh-Guldberg O (1999) Climate change, coral bleaching and the future of the world's coral reefs. Mar Freshw Res 50:839-866

Kaniewska P, Campbell PR, Kline DI, Rodriguez-Lanetty M, 
Miller DJ, Dove S, Hoegh-Guldberg O (2012) Major cellular and physiological impacts of ocean acidification on a reef building coral. PLoS ONE 7:e34659

Knowlton N, Weil E, Weigt LA, Guzman H (1992) Sibling species in Montastraea annularis, coral bleaching, and the coral climate record. Science 255:330-333

Knowlton N, Mate JL, Guzmán HM, Rowan R, Jara J (1997) Direct evidence for reproductive isolation among the three species of the Montastraea annularis complex in Central America (Panama, Honduras). Mar Biol 127: 705-711

> Lasker HR, Brazeau DA, Calderon J, Coffroth MA, Coma R, Kim K (1996) In situ rates of fertilization among broadcast spawning gorgonian corals. Biol Bull (Woods Hole) 190:45-55

Levitan DR, McGovern TM (2005) The Allee effect in the sea. In: Norse EA, Crowder LB (eds) Marine conservation biology: the science of maintaining the sea's biodiversity. Island Press, Washington DC, p 47-57

> Levitan DR, Fukami H, Jara J, Kline D and others (2004) Mechanisms of reproductive isolation among sympatric broadcast-spawning corals of the Montastraea annularis complex. Evolution 58:308-323

Levitan DR, Fogarty ND, Jara J, Lotterhos KE, Knowlton N (2011) Genetic, spatial and temporal components of precise spawning synchrony in reef building corals of the Montastraea annularis species complex. Evolution 65: $1254-1270$

Levy O, Appelbaum L, Leggat W, Gothlif Y, Hayward DC, Miller DJ, Hoegh-Guldberg O (2007) Light-responsive cryptochromes from a simple multicellular animal, the coral Acropora millepora. Science 318:467-470

Liu G, Strong AE, Skirving W (2003) Remote sensing of sea surface temperature during 2002 Barrier Reef coral bleaching. EOS Trans Am Geophys Union 84:137-144

Lopez JV, Kersanach R, Rehner SA, Knowlton N (1999) Molecular determination of species boundaries in corals: genetic analysis of the Montastraea annularis complex using amplified fragment length polymorphisms and a microsatellite marker. Biol Bull (Woods Hole) 196:80-93

Mendes JM, Woodley JD (2002) Effect of the 1995-1996 bleaching event on polyp tissue depth, growth, repro-

Editorial responsibility: Steven Morgan,

Bodega Bay, California, USA duction and skeletal band formation in Montastraea annularis. Mar Ecol Prog Ser 235:93-102

Oliver J, Babcock R (1992) Aspects of the fertilization ecology of broadcast spawning corals: sperm dilution effects and in situ measurements of fertilization. Biol Bull (Woods Hole) 183:409-417

Pandolfi JM, Budd AF (2008) Morphology and ecological zonation of Caribbean reef corals: the Montastraea 'annularis' species complex. Mar Ecol Prog Ser 369:89-102

> Suzuki A, Gagan MK, Fabricius K, Isdale PJ, Yukino I, Kawahata H (2003) Skeletal isotope microprofiles of growth perturbations in Porites corals during the 19971998 mass bleaching event. Coral Reefs 22:357-369

Sweeney AM, Boch CA, Johnsen S, Morsel DE (2011) Twilight spectral dynamics and the coral reef invertebrate spawning response. J Exp Biol 214:770-777

Szmant AM (1991) Sexual reproduction by the Caribbean reef corals Montastrea annularis and M. cavernosa. Mar Ecol Prog Ser 74:13-25

Szmant AM, Gassmann NJ (1990) The effects of prolonged 'bleaching' on the tissue biomass and reproduction of the reef coral Montastrea annularis. Coral Reefs 8:217-224

> Szmant AM, Weil E, Miller MW, Colon DE (1997) Hybridization within the species complex of the scleractinian coral Montastraea annularis. Mar Biol 129:561-572

> Van Veghel MLJ (1994) Reproductive characteristics of the polymorphic Caribbean reef building coral Montastrea annularis. I. Gametogenesis and spawning behavior. Mar Ecol Prog Ser 109:209-219

- Van Veghel MLJ, Bak RPM (1994) Reproductive characteristics of the polymorphic Caribbean reef building coral Montastrea annularis. III. Reproduction in damaged and regenerating colonies. Mar Ecol Prog Ser 109:229-233

Van Veghel MLJ, Kahmann MEH (1994) Reproductive characteristics of the polymorphic Caribbean reef building coral Montastrea annularis. II. Fecundity and colony structure. Mar Ecol Prog Ser 109:221-227

Weil E, Knowlton N (1994) A multi-character analysis of the Caribbean coral Montastraea annularis (Ellis \& Solander, 1786) and its two sibling species, M. faveolata (Ellis \& Solander, 1786) and M. franksi (Gregory, 1895). Bull Mar Sci 55:151-175

Submitted: July 8, 2014; Accepted: September 30, 2014 Proofs received from author(s): November 4, 2014 